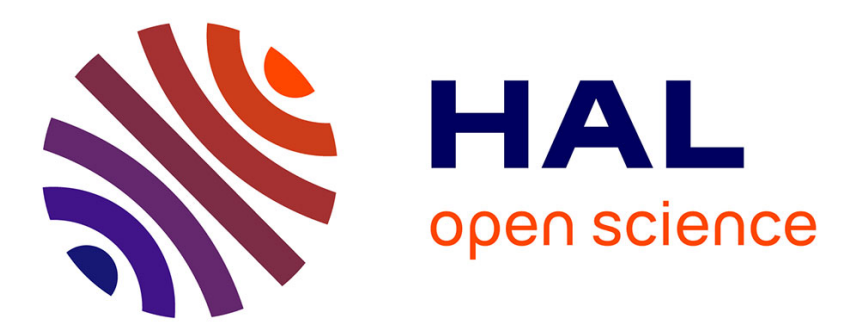

\title{
Targeting rural development interventions : empirical agent-based modeling in Nigerien villages
}

Mehdi Saqalli, B. Gérard, C. Bielders, Pierre Defourny

\section{To cite this version:}

Mehdi Saqalli, B. Gérard, C. Bielders, Pierre Defourny. Targeting rural development interventions : empirical agent-based modeling in Nigerien villages. Agricultural Systems, 2011, 104 (4), pp.354-364. halshs-00921027

\section{HAL Id: halshs-00921027 https://shs.hal.science/halshs-00921027}

Submitted on 19 Dec 2013

HAL is a multi-disciplinary open access archive for the deposit and dissemination of scientific research documents, whether they are published or not. The documents may come from teaching and research institutions in France or abroad, or from public or private research centers.
L'archive ouverte pluridisciplinaire HAL, est destinée au dépôt et à la diffusion de documents scientifiques de niveau recherche, publiés ou non, émanant des établissements d'enseignement et de recherche français ou étrangers, des laboratoires publics ou privés. 


\title{
Targeting rural development interventions: Empirical agent-based modeling in Nigerien villages
}

\author{
M. Saqalli ${ }^{\text {a,*}}$, B. Gérard ${ }^{\text {b }}$, C.L. Bielders ${ }^{c}$, P. Defourny ${ }^{c}$ \\ ${ }^{a}$ REEDS International Centre, Université Versailles St-Quentin-en-Yvelines, Guyancourt, France \\ ${ }^{\mathrm{b}}$ ILRI, Addis-Abeba, Ethiopia \\ ' Université catholique de Louvain, Louvain-la-Neuve, Belgium
}

\section{A R T I C L E I N F O}

\section{Article history:}

Received 9 October 2009

Received in revised form 1 December 2010

Accepted 16 December 2010

Available online $\mathrm{xxxx}$

\section{Keywords:}

Farming systems

Individual agent-based model

Niger

Sahel

Development interventions

\begin{abstract}
A B S T R A C T
The aim of this article is to analyze the impact of development interventions on the population of three Nigerien villages that differ in terms of their agro-ecological, social and economic characteristics. This is performed by simulating the behavior of individuals in an agent-based modeling framework which integrates the village characteristics as well as the family internal rules that condition access to economic and production activities. Villagers are differentiated according to the social and agro-ecological constraints they are subjected to. Two development project interventions are simulated, assuming no land scarcity: increasing the availability of inorganic fertilizers for farmers and an inventory credit technique based on millet grain. Two distinct approaches were used to model the rationale of farmers' decision making: gains or losses in economic value or gains or losses in within-village "reputation". Our results show that village populations do not respond en masse to development interventions. Reputation has little effect on the population behavior and should be considered more as a local proxy for wealth amongst villagers, suggesting the monetization of these societies. Populations involve themselves in the two simulated development interventions only at sites where savings are possible. Some level of household food security and investment capacity is actually required to take part in the development interventions, which are largely conditioned by family manpower and size. As long as uncultivated land remains available in the village territory, support for inorganic fertilizers has little impact in the absence of any intensification process. Inventory credit engages a maximum of $25 \%$ of the population at the site with medium agro-ecological conditions. Therefore, both interventions should be viewed as a potential support tool for a limited part of the population capable of going beyond the survival level, but not as a generic poverty-alleviation panacea.
\end{abstract}

(c) 2010 Elsevier Ltd. All rights reserved.

\section{Introduction}

The low impact that development specialists have had on rural societies in Sahelian Africa for half a century has created a huge debate within and between scientific disciplines, but also in the development arena (Hambally, 1999; Lavigne-Delville, 1999; Mortimore and Adams, 2001). This debate intensified after the food crisis Niger suffered in 2005 (Médecins Sans Frontières, 2005; Harragin, 2006). In view of this recurrent failure of development interventions to meet their goals, development specialists have been urged to improve the relevance and the efficiency of their interventions (Decoudras, 1990; Watkins and von Braun, 2004; Dollar and Levin, 2006).

* Corresponding author. Tel.: +33 (0) 6160380 37/+33 (0) 1392556 25; fax: +33(0) 139255016 .

E-mail address: saqalli@lmtg.obs-mip.fr (M. Saqalli).
As for any action, a development action should integrate a "marketing" strategy: who are the target population groups, what is the expected impact of such interventions on the environment and society, and what are the factors that condition the impact of the intervention within a population? In the case of development interventions aimed at supporting agricultural production in the Sahel, it is generally very difficult to verify ex-ante whether the targetted population groups are indeed the beneficiaries of the development actions or whether the actual impact will meet expectations given the inherent complexity of the village production systems Biershenk et al. (2000). Indeed, land tenures are varied and complex (Le Bris et al., 1991; Lavigne-Delville, 1998; McCarthy et al., 2000). Strong interactions between on- and offfarm production activities and consumption decisions (de Janvry and Sadoulet, 2003), the division of assets amongst villagers and family members as well as multipurpose strategies are some additional socio-economic variables that may affect the outcome of the development interventions. All these elements cannot be analyzed 
in a systematic and/or an experimental manner (Ahrweiler and Gilbert, 2005), which justifies the use of a modeling approach. As reviewed by Lambin et al. (2001) and Bousquet and Le Page (2004), agent-based models (ABMs) have been found particularly useful for simulating the multi-disciplinary and multipurpose reality of the rural world. The purpose of the present article is therefore to identify the target groups and evaluate the potential impact of two development interventions by means of an $A B M$ modeling approach.

The two selected interventions are emblematic of agricultural development strategies in Niger and are generally viewed by donnors and development specialists alike as non-discriminant, i.e., all population groups involved in agriculture may potentially benefit from them. The first intervention considered here is support for the use of inorganic fertilizers. Niger having one of the lowest inorganic fertilizer use rates in the world $(0.27 \mathrm{~kg} / \mathrm{ha})$, inorganic fertilizers are considered by many development specialists as the bottleneck for rainfed cropping intensification and higher income generation (de Rouw and Rajot, 2004; Ouédraogo, 2005). The aim is to promote the use of inorganic fertilizers in rainfed food crop production and vegetable gardens. This is achieved, through farmers' organizations, by increasing the availability of inorganic fertilizers at the village-level as well as improving farmers knowledge on their use, with an emphasis on the microdose technology (Tahirou and Sanders, 2005; Gérard et al., 2007). This latter technology improves inorganic fertilizer efficiency and generates less weed pressure than blanket fertilizer applications (Muehlig-Versen et al., 2003). The promoted inorganic fertilizer is di-ammonium phosphate (DAP). Members of farmer organizations can buy inorganic fertilizers at market price. These organizations almost entirely consist of either women or men. They use inorganic fertilizers for gardens, cash crops or cereal fields.

The second intervention considered in the present paper is inventory credit. It is a credit technique which uses non-perishable agricultural produce as a guarantee. This technique is actually implemented in Niger under various modalities, depending on the site, the microfinance institution (MFI) and the farmers association (FA) involved. Usually, part of the farmer's millet grain harvest is stored right after harvest in a reliable warehouse as a guarantee for the credit operator. In exchange, the latter provides a credit equivalent to the value of the stock at the time of the deal, usually around $€ 13.75$ per $100 \mathrm{~kg}$ millet grain bag, from which $10 \%$ is subtracted for storage and transaction fees. The farmer reimburses the credit by buying back his/her stored grain later in the year, usually during the "soudure" period (i.e., the 2 to 3-month period which precedes harvest) when prices have risen as a result of increasing food scarcity and thereby avoids buying millet on the market. The economic benefit that results from the price increase avoidance during the storage period belongs to the farmer. The objective is to provide better access to financial resources (Badamassi, 2006) and to secure farmer income, by compensating for millet price fluctuations (Pender et al., 2006).

\section{Methodology}

For more details regarding the methodology, field data and modeling assumptions, the reader is referred to Saqalli (2008).

\subsection{Description of the study sites}

The program which supported our research was hosted and managed by a consortium of farmers' associations and development and research operators working in Niger. The operators of the consortium had collected extensive literature and data sets over the past 20 years. They were involved in the implementation of the two selected development interventions at 3 contrasted sites of the agro-pastoral zone of Niger (Fig. 1): Zermou in the region of Zinder, Gabi in the region of Maradi and Fakara in the region of Tillabery. The latter was the main location where we elaborated our social hypotheses, which were then extended to the two other sites with the support of the available literature (Luxereau and Roussel, 1997; Waziri Mato, 2000; Mortimore et al., 2001; Jouve, 2003; Yamba, 2005).

The three sites are: (i) situated in areas with rainfed agriculture, (ii) close to a regional urban pole, and (iii) linked to the main farming ethnic groups of the country (Zarma around Niamey, Hausa in Maradi, and Hausa/Hausa-speaking Kanuri in the region of Zinder). Furthermore, they are (iv) considered as poorly resources-endowed, and ( $v$ ) they have been actively researched and subjected to development actions by operators working for more than ten years in Niger (Gérard, 2002). Each site covers an area of about $2000 \mathrm{~km}^{2}$. The main differences between the sites are summarized in Table 1. The sites follow a gradient of rainfall and population density from Gabi (wettest and most populated) to Zermou (driest and least populated).

Rainfed millet and sorghum-based agriculture is the main activity at all sites, both in terms of land use and manpower requirements. It is managed in an extensive and anti-risk approach. The rainfed part of the country experiences a low to moderate rainfall between 200 and $800 \mathrm{~mm}$, distributed in a single rainy season from June to October, but its main characteristic is its high spatial and temporal intra-annual and inter-annual variability (Akponikpe et al., 2011). Soils have a very low fertility as well as a poor water and cation retention capacity (Graef and Haigis, 2001). Manure is

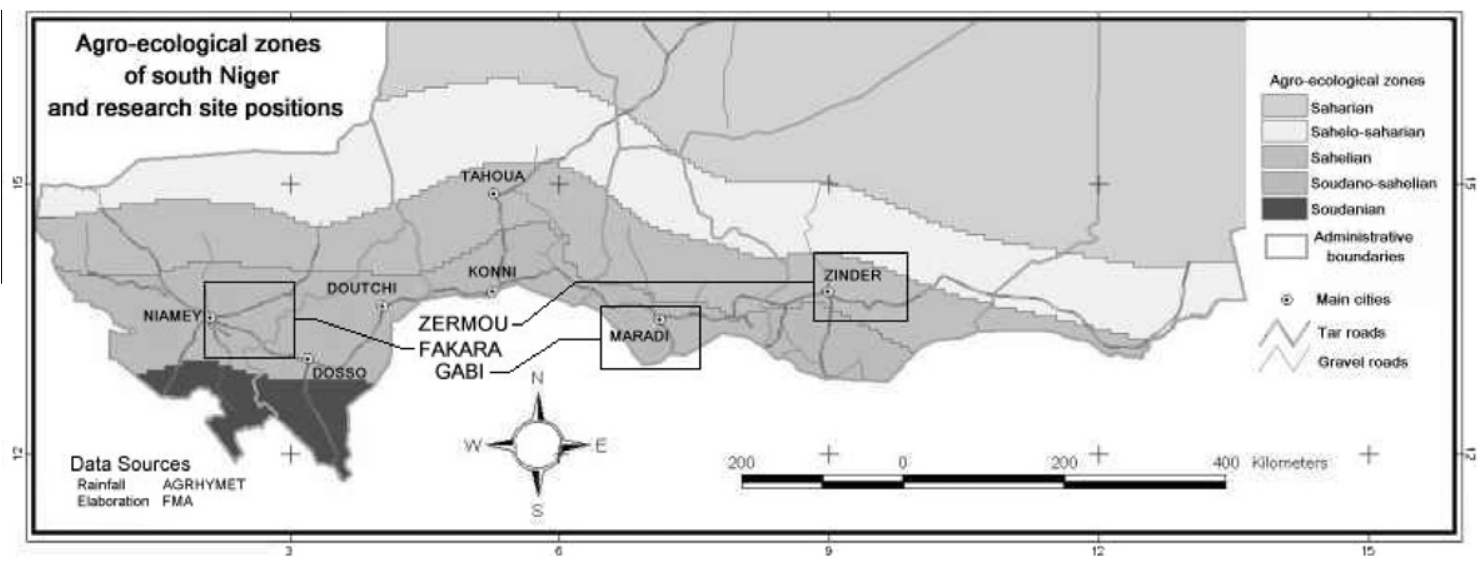

Fig. 1. Rainfed Niger and location of the three study sites. 
Table 1

Factors differentiating the three sites as implemented in the SimSahel model.

\begin{tabular}{|c|c|c|c|c|c|c|c|c|c|}
\hline & \multicolumn{3}{|c|}{ Zermou } & \multicolumn{3}{|l|}{ Fakara } & \multicolumn{3}{|l|}{ Gabi } \\
\hline Location & \multicolumn{3}{|c|}{ Zinder Region, Eastern Niger } & \multicolumn{3}{|c|}{ Tillabery Region, Western Niger } & \multicolumn{3}{|c|}{$\begin{array}{l}\text { Maradi Region, Central } \\
\text { Niger }\end{array}$} \\
\hline \multirow[t]{2}{*}{ Annual rainfall } & \multirow{2}{*}{\multicolumn{3}{|c|}{$\begin{array}{l}\text { Mean: } 350 \mathrm{~mm} \\
\text { Variability: } 70-525 \mathrm{~mm}\end{array}$}} & \multicolumn{3}{|c|}{ Mean: $450 \mathrm{~mm}$} & \multicolumn{3}{|c|}{ Mean: $550 \mathrm{~mm}$} \\
\hline & & & & Variabil & $-675 r$ & & Variabi & $275-$ & $5 \mathrm{~mm}$ \\
\hline Average soil fertility & \multicolumn{3}{|c|}{ Poor } & \multicolumn{3}{|c|}{ Average } & \multicolumn{3}{|c|}{ Good } \\
\hline \multirow[t]{2}{*}{ Soil arability proportion $\left(\%^{\circ}\right)$} & Valley & Plain & Stony hills & Valley & Plain & Plateaus & Valley & Plain & Hills \\
\hline & 0.1 & 69.9 & 30.0 & 3.9 & 79.6 & 16.5 & 18.1 & 60.0 & 21.9 \\
\hline Initial Agronomic potential ${ }^{*}$ & 2 & 1 & 0 & 2 & 1 & 0 & 2 & 1 & 0,5 \\
\hline Access to shallow water & Yes & No & No & Yes & No & No & Yes & No & No \\
\hline Migration destination \& impact on other activities & \multicolumn{3}{|c|}{$\begin{array}{l}\text { Gardening incompatible with } \\
\text { migration }\end{array}$} & \multicolumn{3}{|c|}{$\begin{array}{l}\text { No competition between gardening \& migration } \\
\text { because of the gender differentiation }\end{array}$} & \multicolumn{3}{|c|}{$\begin{array}{l}\text { Gardening compatible with } \\
\text { migration }\end{array}$} \\
\hline \multirow[t]{2}{*}{ Migration constraints } & & \multicolumn{3}{|c|}{ Transport costs: 30 kFCFA } & \multirow{2}{*}{\multicolumn{3}{|c|}{$\begin{array}{l}\text { Transport costs: } 5 \text { kFCFA } \\
\text { Racketeering risks: } 0.5 \%\end{array}$}} \\
\hline & \multicolumn{3}{|c|}{ Racketeering risks: $2 \%$} & \multicolumn{3}{|c|}{ Racketeering risks: $1 \%$} & & & \\
\hline Women activity & \multicolumn{3}{|c|}{ Sheep raising } & \multicolumn{3}{|c|}{ Sheep raising \& gardening } & \multicolumn{3}{|c|}{ Sheep raising } \\
\hline Men activity & \multicolumn{3}{|c|}{ Farming, migration \& gardening } & \multicolumn{3}{|c|}{ Farming \& migration } & \multicolumn{3}{|c|}{$\begin{array}{l}\text { Farming, migration \& } \\
\text { gardening }\end{array}$} \\
\hline Present-time inheritance system $^{\mathrm{a}}$ & \multicolumn{3}{|c|}{ Local traditional } & \multicolumn{3}{|c|}{ Local traditional } & \multicolumn{3}{|c|}{ Local Muslim } \\
\hline
\end{tabular}

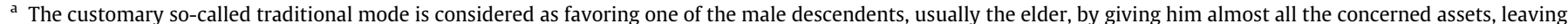

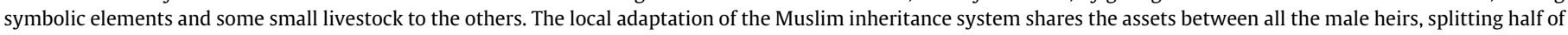
the heritage to the brothers of the dead and half to his sons.

the main local fertilization method, but it is not available in quantities large enough to meet demand (La Rovere, 2001), while at the same time inorganic fertilizers are still expensive.

Male farmers migrate during the dry season, from October to May, usually to work as small-scale traders (Rain, 1999; Timera, 2001). The money they bring back home is an important source of income for the remaining family members, around $€ 290$ per family per year (Reardon, 1994; Mounkaïla, 2003; Saqalli et al., 2010). These funds are mainly used to fulfill food requirements that agriculture no longer satisfies, for male ostentation purposes such as cigarettes or sunglasses, and to cover expenses for social (i.e., marriage) and religious (i.e., Tabaski, the main Muslim feast) ceremonies. For instance, each marriage can cost $€ 1150$, shared among the community. In addition, a dowry is given to the bride's family, a sum equivalent to two bulls, i.e. almost $€ 300$. In addition, migrants buy small ruminants upon returning from migration. This allows them to withdraw some cash from the constant requests of the family at large but also, after selling the animal, to pay for the travel expenses of the next migration, usually just after crop harvest (Saqalli et al., 2010).

Dry season vegetable gardening can be practiced only in some villages where wells provide access to shallow groundwater in thalweg fields. Social access to gardening varies according to the site. At the Fakara site, it is currently restricted to married and respectable women with family manpower, who borrow fields after millet harvest. This activity provides on average $€ 52.50$ per gardener per year (Saqalli et al., 2010). Gabi has seen a shift in the gardening activity from a female-driven traditional activity to a pure male activity. This is due on the one hand to a better access to markets and the availability of a large acreage of land suitable for irrigation, which results in a greater profitability of gardening at Gabi compared to the other sites and hence attracts a growing number of male gardeners. On the other hand, women are more and more kept away from fields as a result of a growing social pressure. The site of Zermou has experienced the same social shift but is endowed with only a very small acreage of land suitable for vegetable cropping.

\subsection{Overall modeling approach and assumptions}

The overall research methodology was based on an iterative process between field investigations, discussions with local experts, and modeling. Model rule development was supported by a two-year field investigation and participatory observation period in several groups of villages and local organizations, similar to the investigation method described by Bogdan and Taylor (1975). Repetitions along interviews and cross-checking between sources were the criteria used for validation of the model rules. The rules were then compared to behavior descriptions and rules described in the available literature. As for the model rules, the different modeling scenarios were also defined on the basis of field observations, discussions with experts and a literature review.

Our strategy was to combine rather than juxtapose different disciplines in a single comprehensive model, in order to compare both development interventions in terms of impact on the population under different local environments. Consequently, we did have to formulate numerous hypotheses:

1. The success of a development intervention is not defined by its very characteristics but results from the villagers perception of this intervention, whatever its intrinsic quality. The factors and constraints selected for implementing a development intervention in the model are thus defined on the basis of the villagers' perception.

2. The model is individual-based: the behavior of each villager agent depends on his own social characteristics and constraints, in order to combine at this very level all the complexity and the specificity of each individual in a village (Deffuant et al., 2002). Modeling individual behavior rather than household behavior was selected because it has been shown previously, and confirmed by our own investigations, that the "household" unit is not a relevant concept for sahelian rural situations (Gastellu and Dubois, 1997; Saqalli et al., 2010).

3. The model is empirical, and villager behavior and processes are reactive rather than cognitive. Villagers simply do what they have to do and react as a function of time and events without cognitive functions that would require absolute rather than relative parameterization of social values. The only cognitive function of the villagers pertains to their involvement in a development intervention (see Section 2.4.3). The different activities are implemented in the simplest possible way in order to maintain the global consistency of the system.

4. Considering all the components of a system and simplifying them appeared more relevant than focusing on the one component which seems a priori to be the most important (Alacs, 2004; Amblard and Phan, 2006). This model is therefore not based on the binary relationship between a villager and the development intervention but the development intervention is just one component guiding the activities of a villager agent. 


\subsection{Field investigation methodology}

\subsubsection{Assessing the organization of a rural village}

The agro-ecological part of the model was developed on the basis of data available in the literature (La Rovere, 2001; Gérard, 2005). Millet price and rainfall data as well as the functions relating millet growth to fertility and rainfall came from ICRISAT and ILRI databases.

The social part of the model was developed through the following: (1) transects and local perception-based regional maps (Saqalli et al., 2009). These maps, and the information collected for drawing them, allowed to identify the villagers' hierarchy of variables that characterize the biophysical environment. In addition, the maps guided the selection of villages in which we carried out individual interviews. (2) Participatory Research Assessments (PRAs) were carried out in 8 villages using the methodology and principles of Chambers (1994). (3) 175 semi-direct individual interviews across 28 villages focused on the main activity carried out by the interviewed person at the time of the interview. (4) A review of the available published and grey literature.

\subsubsection{Assessing the practical mode of implementation of development actions}

Our long-term field investigation also allowed investigating the complex relationship between development projects and villagers, and assessing the practical implementation of development interventions. We tried to analyze these actions both from the project's point of view and the villagers' one, using a participatory observation approach. The best moment for observation appeared to be the time when both social groups met, during meetings, visits and interview times. We first used the project's official documents or documents coming from other projects as a framework that could be modified to accomodate unofficial expert communications and local situations.

The analysis of the development specialists' practices was done through different cross-checkable methods: (1) 4-12 villagers for each study site were re-interviewed on their personal relations with the development projects. These persons were selected on the basis of their gender and level of responsibility and their will to interact. In the same way, nine elders were interviewed on their perceptions of the history of local development actions; (2) the results of development interventions are recorded in village-based registers that we collected and compared with head office' records but also with our own semi-direct interview data; (3) by staying in villages and remaining as unobtrusive as possible, our everyday presence allows transactions and comments between villagers and development stakeholders to be observed with a low level of perturbation, and so to have access to the interface between the project corpus and the village.

\subsection{Agent-based modeling}

The selected ABM platform is Common Resources Management Agent-based System (CORMAS) developed by CIRAD (Bousquet et al. 2001). The model was split into an agro-ecological part and a socio-economic part (Fig. 2). The main model functions are described below in a qualitative way. Further details regarding the functions and modeling methodology can be found in Saqalli et al. (2010) and Saqalli (2008).

\subsubsection{Building the village module}

Individual agents are defined as equivalent, which means that they have the same attributes: only the values of these attributes vary, defining each agent and its characteristics (Verhagen and Smit, 2003).
At the model initialization, fifty villager agents are created in the virtual environment. Initial villager agents are from various ages (from 1 to 55 years old), gender, lineages (with a hierarchy from 1 to 4 , as a measure of the powerfullness of each kinship group in the village) and land property (between 3 and 5 map cells of 1 ha each). After the initialization step, gender and family rank for a villager agent are the most important factors within the village context. These two factors determine the access to all the social and/or economic activities, i.e., marriage, property, food and money redistribution, millet farming, gardening (Zermou and Gabi) and migration for men, gardening for women (Fakara only). Ranks are defined for all child agents but evolve for all adult agents in each family. They are updated at the beginning of each time step, as a function of newborns, new marriages, reaching adulthood and deaths. The head of the family possesses the highest rank. However, the family's head does not manage the entire multi-activity system of the family but only millet farming activities. Other activities (livestock-keeping, migration, gardening, food redistribution) are under the sole responsibility of the individuals: each villager agent should sustain itself but also its dependents, i.e., all people in the family with a lower rank and directly related to him. This includes all the children but also younger brothers and sisters, and all wives for the husbands.

Families can expand their land properties only if the family annual consumption requirement is higher than the millet production of the previous season. This happens quite often in the case of Zermou (AQUADEV, 2006). The extension capacity depends on the lineage values, the ratio between the available family manpower and the family size (Gavian and Fafchamps, 1996), and a distance-to-village opportunity cost factor (Loireau-Delabre, 1998). The manpower unit is defined as the Farming Labor Unit (FLU). Based on our observations, female and male adult manpower are considered equivalent and equal to 1 , not withstanding the fact that female manpower may occasionally be more important in practice. We condition the child manpower capacity on age, i.e., for a child $i$ in the village: Manpower $(i)=$ Age $(i) / 20$. Adulthood is reached at an age of 16 . Only married adult males can have access to land ownership. As a strict condition to become a village "citizen", each male adult agent has to marry at least once, but may marry up to four times. Saving enough money to afford the dowry is therefore an essential social step for each bachelor.

The model has a weekly time step. It is spatialized through a dynamic cellular automata matrix of the model, where each pixel is a parcel of the village territory. Soil characteristics and rainfall are attributed to each pixel based on a data-derived map of soil characteristics (fertility, access to shallow water) and the rainfall spatial variability as observed from the local ICRISAT raingauge network (Gérard, 2005; Akponikpè et al., 2011). Biophysical and farming processes are defined for each pixel as identified by the villagers and from literature data.

\subsubsection{Simulating villagers' production activities}

2.4.2.1. Agriculture. Only male adult agents can crop millet fields during rainy seasons at all three sites. They can garden on borrowed fields during dry seasons at the Maradi and Zermou sites. For the Fakara site, the latter activity is restricted to female adult agents. The sequence of cropping actions a male adult agent should follow (sowing, weeding once or twice and harvesting) is conditioned by a diagnosis of available manpower and minimization of expected production losses. Crop growth is governed by the available manpower a villager agent can mobilize to carry out the right cropping action at the right time, defined by rainfall distribution and by the fertility rate at each time step. A parcel's fertility evolves as a function of crop growth, a weed impact factor and the amount of manure applied during dry seasons. Crop yields re- 


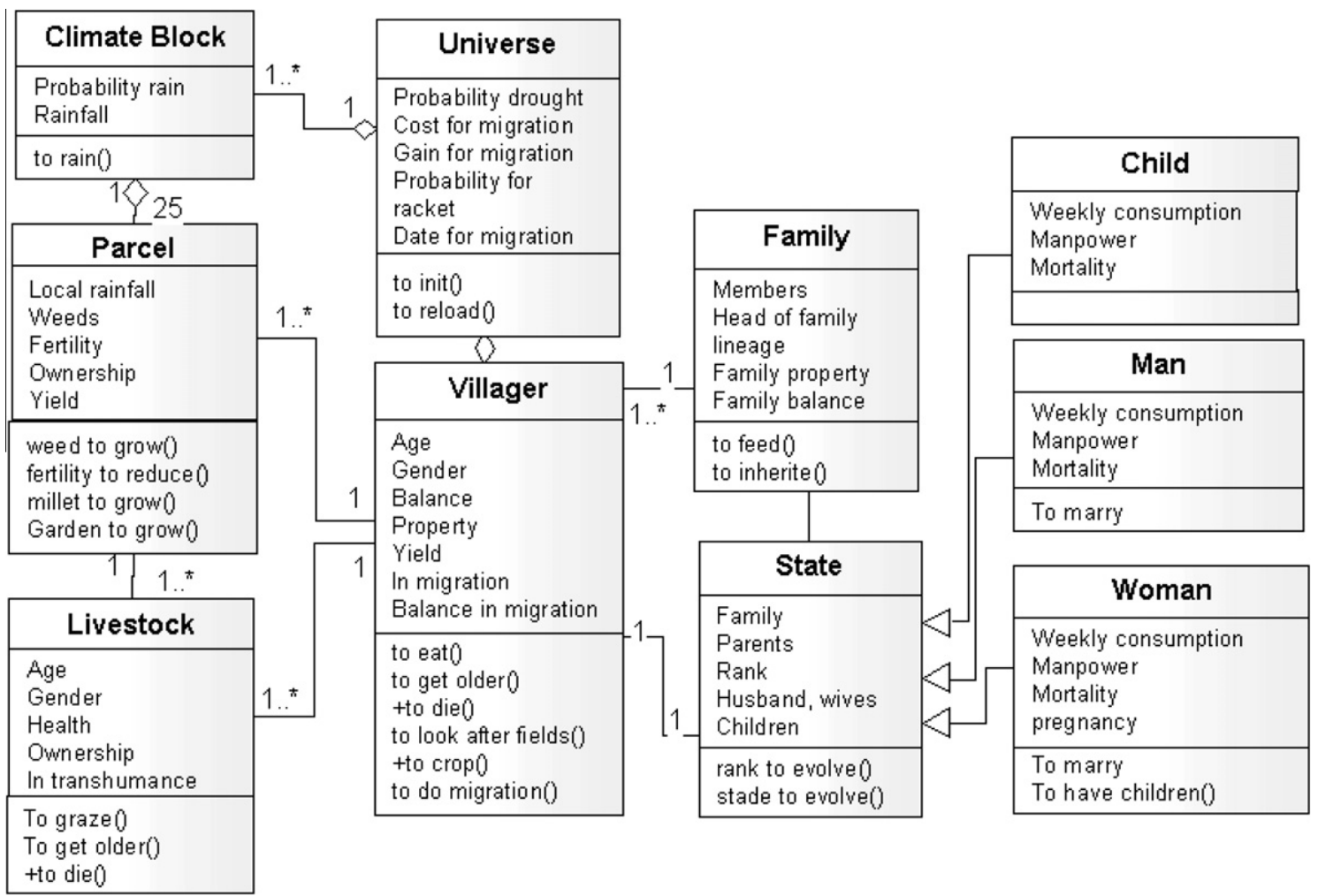

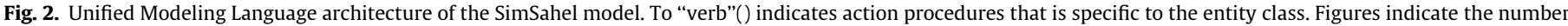

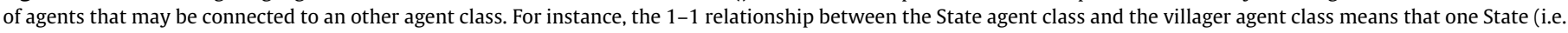

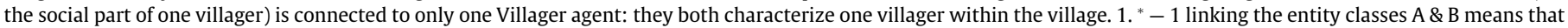
at least one until an infinite member of agents of class A can belong to $(-\diamond)$ or be linked with $(-)$ one and only one B class entity.

sult from a combination of the crop growth and harvesting time, weeds, fertility and management.

2.4.2.2. Gardening. In Fakara, female adult agents follow an equivalent sequence of actions for their dry season vegetable gardening. Only married female adult agents with stepdaughters or with unmarried daughters at least 12 years old can have access to gardening. They can mobilize the available female manpower from then on in a similar to the head of the family for millet farming. In Zermou and Gabi, gardening is restricted to men and follows the same pattern as in Fakara.

2.4.2.3. Migration. Only male adult agents more than 16 years old have access to the migration activity. The price for the roundtrip travel is the major constraint for leaving. The date of departure depends on the family rank, i.e., the number of dependent relatives. The weekly gain in income during migration is a function of the location, season, and number of years of experience. To return home, the migrant should overcome two constraints: (1) for prestige reasons, a male adult agent cannot return to his village without a minimum amount of money, at least the roundtrip ticket for the next migration, i.e. $2 * 45.75 €$; (2) Each migrant agent has a certain probability of being fradulently charged by customs agents he meets (racketeering risks in Table 1).

2.4.2.4. Livestock keeping. It is here limited to a saving scheme. Each year, individual gains (crop production, migration, gardening) can be transformed into livestock, with a depreciation factor. If family yields are good enough, villager agents buy animals after crop harvest, when they have grain to sell, even though millet price is lowest at that time (around $€ 13.75$ per $100 \mathrm{~kg}$ bag). When the granary is almost empty, they sell animals to buy millet, but at that period, millet price is high ( $€ 27.50$ per bag on average). This $50 \%$ loss can be considered as a livestock keeping cost. Upon returning from migration, the migrants buy small ruminants they feed during the rainy season. At harvest or sometimes before, they are sold to pay for the travel expenses of the next migration. Animal fattening is in this case considered as compensating the 50\% loss.

2.4.2.5. Fertility management and manure. Three fertility restauration processes are considered. The natural regeneration by shrub and weed growth is simulated through a series of functions of fertility originated from simplification factors derived from d'Herbès et al. (1997) and Wesel et al. (2000). Animal manure is applied to fields in two ways. Animals graze during day time across the territory (Table 1 ), with no human management. Half of the animal faeces is thus spread in the grazed areas. The other half is applied through corraling at night (Ayantunde et al., 2000; Ayantunde et al., 2002), which allows villagers to fertilize fields selected on the basis of their distance-to-village and fertility level.

\subsubsection{Assessing development action types}

Development interventions are gender-specific. Inventory credit and fertilizers are proposed to villagers at $t=0$. For each adult and married villager, choosing to be involved in one of the actions is the only cognitive function included in the model: it is based on personnal experience, i.e., a comparison of gains in annual income with or without taking part in the development action. The gain is based on food and income stock. In the absence of experience, all adult villager Agents who manage millet fields or gardens try the development action for the coming year.

2.4.3.1. Inventory credit. The decision to take part in the inventory credit system is taken after harvest. When viewed as a form of sav- 
ing, the first step towards participation in the inventory credit is to determine if the agent (i.e., the head of the family or, if absent, the highest ranking adult) has the capacity for saving. Hence, we consider that every villager needs to keep at least enough millet to feed all the family members who rely on him/her for half a year:

$\mathrm{SM}_{\mathrm{fi}}(t)>\mathrm{CA}_{\mathrm{di}}(t) / 2$

With di: the number of family members of $i$ relying on $i$ at time $t$; $\mathrm{SM}_{\mathrm{fi}}(t): i$ family millet stock at $t ; \mathrm{CA}_{\mathrm{di}}(t)$ : annual food consumption of the dependents di;

The second step is then a cognitive decision based on personal experience, through a comparison of the mean gain achieved during past years with saving through inventory credit and the mean gain achieved during past years with no inventory credit or with saving through livestock:

$W_{i}(t-1)>N W_{i}(t-1)$

With $W_{i}(t-1)$ : the total "gain" of the family of all the previous years when inventory credit was used, including the difference in cash of the value of the livestock; $N W_{i}(t-1)$ : the total "gain" of the family of all the previous years without inventory credit, including the difference in cash of the value of the livestock as well. The "gain" is either "reputation" in the reputation scenario or "income" in the economic scenario.

2.4.3.2. Fertilizers. Inorganic fertilizer application is possible throughout the millet cropping season. Only millet field or vegetable garden managers can buy fertilizers. The price of the bag of inorganic fertilizers is $50 \mathrm{kFCFA}(€ 75)$. According to the hill-placed fertilizer ("microdose") recommendations (Tahirou and Sanders, 2005), 0.2 bags of inorganic fertilizer is needed for a 1-ha parcel, meaning that fertilizing one cell in the model costs 10 kFCFA $(€ 15)$. Gardens require 10 times this amount, such that fertilizing a garden also costs $€ 15$ since we consider that one garden is one tenth of a cell. Farmers select the fields which brought to his family more wealth across all previous years with inorganic fertilizers than without and rank them according to the wealth gain they brought. After setting aside at least enough millet and/or cash to satisfy the food requirements of him/herself and his/her dependants for half a year, the rest of his/her savings is considered as his/her financial ability to buy fertilizers. This ability is in millet and cash stock only, the sale of livestock cannot serve as a source of cash to buy fertilizers, as we never observed anybody selling animals to buy fertilizers. This is consistent with the general assumption that animals should be considered as savings or speculation products by themselves but not as a means to invest in technologies that allow an increase in agricultural productivity. Relevant fields are then fertilizer to the extent the farmer can afford it. The ability to invest in fertilizers is based on the following rule:

$\mathrm{SM}_{\mathrm{fi}}(t)+\mathrm{SC}_{\mathrm{fi}}(t)>N F_{i}(t)$

With $\mathrm{SM}_{\mathrm{fi}}(t)$ : the value of the millet stock of the family $i$; $\mathrm{SC}_{\mathrm{fi}}(t)$ : cash stock of the family $i$; $N F_{i}(t)$ : the value of the inorganic fertilizers needs based on the acreage which brought more wealth to the family across all previous years with fertilizers than without. When the condition of Eq. (3) is met, a farmer can fertilize as many fields as he can afford. Inorganic fertilizers have an immediate effect on millet, which depends on the crop development stage (maturing and harvest stages). During the maturing stage, there is a risk of $1 \%$ per rainy week of crop failure in fertilized fields because of the chemical burn that can occurs (de Rouw, 2004; Koning and Smaling, 2005).

For each site, thirty 60-year simulations were run. Hence each simulation covers 3120 weekly time steps, i.e., two generations. Simulation outputs were obtained for the entire village, at family level and at gender and age group levels. Village-level simulation results are compared to available data, i.e., our macro level field investigation results, literature review and the Niger national census, in order to assess the consistency of the model. The two development interventions are then compared individually or in combination. As the founding of the village occurs at $t=0$, the first 5 years should not be considered as part of the simulation results as they are strongly affected by the initialization process.

\section{Simulation results}

A confidence building step and a sensitivity analysis of the model have been carried out, whose results are discussed in Saqalli et al. (2010). These results provided enough confidence in the model for its further use for thematical analyses such as the one addressed in the present paper, both in terms of the reliability of its outputs compared to external data and with respect to the simulated individual and collective behaviors compared to our observations and the relevant literature.

\subsection{Comparison of sites in the absence of development interventions}

\subsubsection{Production assets: a structural geographic advantage}

Average income per capita at first follows a convex curve because of the generation effect: a very high adult per capita ratio during the first 5-10 years has positive effects on income (Saqalli, 2008). However, as a result of the "baby boom" during the years 15 to 30 , the slope of the income curves gradually becomes negative at all three sites (Saqalli, 2008). Nevertheless, both the absolute value of the income and the simulated amplitude of the income variations vary depending on the site: Fakara and Gabi show very similar declining curves with a large decrease in income between the years 15-60, whereas income at Zermou remains significantly lower at all times yet the variation in income is smaller during the same period. Better biophysical (higher rainfall and soil fertility) and economic conditions (lower migration, costs) in Fakara and Gabi allow for higher individual income, which facilitates access to marriage for men. This in turn reduces the delay for getting children, which results in a decrease in the adult per capita ratio at these two sites and consequently decreases income per capita despite the overall better income.

Cropland acreage increases faster at Zermou than at the two other sites because yields are very low at this site and the decision to expand fields is conditioned by the food production level. The land per capita ratio is therefore higher at this site than at the two other sites during the first half of the simulation period. However, as the manpower ratio of Zermou remains quite equivalent to the two other sites, villagers at Zermou do not benefit from this rapid field expansion as they cannot crop all the cropland properly. Consequently, population growth is significantly lower for Zermou (321 \pm 97 inhabitants after 60 years) compared to the Fakara (585 \pm 141 inhabitants) and Gabi (505 \pm 131 inhabitants) (Saqalli, 2008). The substantial differences between Zermou and the two other sites suggest that the Zermou site has exceeded a threshold resulting from the accumulation of greater constraints.

\subsubsection{Distribution of activities: site-specific specialization}

All three activities (agriculture, migration and gardening) grow in volume because of the demographic growth.

Per capita income from millet cropping varies according to the site: Zermou shows a constant decline in farming income and even a shift in the allocated labor from farming to migration between the 15 th and the 25 th year (i.e., after the very rapid period of field extension). The two other sites have similar trends. After a period of fairly constant income per capita ( $0-15$ years), income per capita from agriculture rises rapidly (15-30 years) due to the progressive 
appropriation of new lands during this period of fast population growth, which does not occur in Zermou. During at least the first half of the simulation, the Fakara population appears to be more involved in farming and has higher farming income than at Gabi. However, this latter site is the only location where farming income per capita remain fairly steady between 35 and 60 years, eventually exceeding the per capita income figures from agriculture in the Fakara during the last 15 years.

For the gardening activity, local social and economic rules dramatically affect the situation. Both the hausa-populated sites of Zermou and Gabi restrict gardening to men. However, at Gabi, the same villager can practice migration and gardening at the same time, thanks to the immediate proximity of Nigeria which allows frequent commuting at low cost, whereas this combination is not possible at Zermou. Consequently, the use of the limited acreage available for gardening at Zermou (Table 1) stops almost completely after a few years of simulation. Gabi sees a progressive increase of the per capita income from gardening. This rise in income is, however, lower than in Fakara, which may have benefited from the gender discrimination between gardening and migration (Table 1). Gardening manpower allocation ratios concern women for the zarma-populated Fakara and men in Gabi.

Regarding migration, the boom in population growth affects migration earlier than farming. Indeed, migration is allowed for men after they reach the age of 16 , even if they are not married, whereas marriage is a prerequisite to farm and "own" land. However, getting married causes the parental support for migration to stop, which lowers the financial ability to migrate. Whereas the three sites show no significant differences in the manpower allocation between the various activities before the population boom (year 10-20), after this period migration seems to suffer from site-specific factors that constrain this activity (Table 1 ): The lower cost for departure and more nearby destination at Gabi allows progressively more people to leave and to bring back home more money than in the Fakara. At the beginning of the simulation, it appears that the accumulation of constraints at the Zermou site (higher departure costs, higher risks, poorer income from agriculture) restricts the extension of this activity. However, the very low income to be gained from agriculture and, the impossibility of doing gardening progressively forces male villagers to reallocate their manpower solely on migration.

\subsubsection{Inequality and sustainability: producing more for how long and for whom?}

As defined by the model rules, the population at the Fakara and Gabi sites expand their fields as a function of their manpower/ population ratios. Cropland acreage grows in Gabi at a nearly steady rate of $4.6 \%$ per year, whereas at the Fakara, this rate is $2.4 \%$ per year and declining over time. As shown in Saqalli et al. (2010), the results for the Fakara are compatible with interpolated field expansion data from 1950 to 1998 . Zermou villagers rapidly conquer the entire village territory, despite the fact that they are not so much involved in farming, because of the far more rapid decline of the fields' fertility at this site. This result is compatible with the literature for various zones in Niger, including the Damagaram where Zermou is located, but also other arable places in Niger for the end of the first half and the beginning of the second half of the 20 th century. This conquering behavior is usually described as a response to manpower scarcity but also as an "investment for the future" at family and village levels (Demont et al., 2007; Bah et al., 2006). Even with lower land occupation growth rates at Gabi and the Fakara, 60 years of continuous growth eventually led to all potential cropland being cropped. This means, however, that further simulation results regarding sustainability and development intervention impacts cannot be compared with the present situation, particularly in Gabi where all available cropland has been cultivated for at least the last 40 years.

After the first cropping years, average yields are not strongly affected by land scarcity. Yields are significantly different between sites as determined by the model inputs and decline slowly from 400 to $550 \mathrm{~kg} / \mathrm{ha}$ at $t=10$ to 350 to $450 \mathrm{~kg} / \mathrm{ha}$ at $t=60$. This resilience cannot be explained by a continuous compensation of the old fields' fertility loss by new fertile land because all available land is already "conquered" at Zermou. It indicates that local farming systems are resilient enough at all three sites to maintain fairly stable, albeit low yields. This yield level allows the populations at the three sites to more or less satisfy their food requirements throughout the simulation period. As people still live at these sites, this simulation result provides some additional confidence regarding the model realism. It is also in broad agreement with Harragin (2006) and Marinho (2007) who considered that food price shocks affect food security more than local food shortages, and with the works of Tabo et al. (2007) whose data show that Niger fertility rates did not actually fall over the last 40 years despite the tripling of the population. Analyzing the evolution of the ratio between the annual per capita consumption and the per capita income from the three main activities and the livestock capital, the model indicates that whereas the ratio strongly increases at Gabi, it remains stable for the Fakara and slightly declines at Zermou, making the latter two sites more prone to food shortage crises.

The evolution of the gender income ratio indicates that it is difficult for women to sustain themselves when having no access to activities, as is the case at Gabi and Zermou. This ratio slightly recovers over time at the Fakara thanks to female access to gardening, which thereby explains the faster income redistribution observed after gardening spread at year 18. The Gini coefficients are indicators for characterizing equity of a population (Dorfman, 1979). Gini index outputs established at family and individual levels suggest another limitation of the three systems: all inequalities between families and within families grow during the 60 years of simulation.

\subsection{Projects implementation: successes and failures}

One should consider these 60 year trajectories with no social evolutions as a way to analyze present-time trends in the present-time social configuration and not as a simulation trial with a prospective purpose.

\subsubsection{A low success mainly due to a poor saving capacity}

Fig. 3 shows the impact of the development interventions. Regarding inventory credit, the initial high values are artifacts, which are due to the first trials needed for villagers to get some personal experience with inventory credit (Figs. 3.1 and 3.3). Fig. 3.3 suggests that the quantity of saved millet strongly depends on the site. At Zermou, yields are too low to both feed people and save millet. Therefore, despite the hope for success of the inventory credit system, local biophysical factors do restrict the potential impact of this intervention as it is based on the assumption of a millet surplus.

Inorganic fertilizer use also shows strong differences among the three sites. Whatever the site, fertilizer use remains very low, with fewer than $10 \%$ of farmers applying fertilizer (Fig. 3.2) and less than $4 \%$ of the total surface being fertilized (Fig. 3.4). The Gabi and Fakara populations show similar behaviors but at different levels: as long as they maintain a high manpower per acreage ratio (between $t=5$ until $t=12$ for Fakara and $t=20$ for Gabi), which allows them to easily clear new fields and to weed cropped fields, farmers do not use inorganic fertilizers. The initial high values are artifacts, which are due to the first trials needed for farmers to get some personal experience with inorganic fertilizers. Gains 

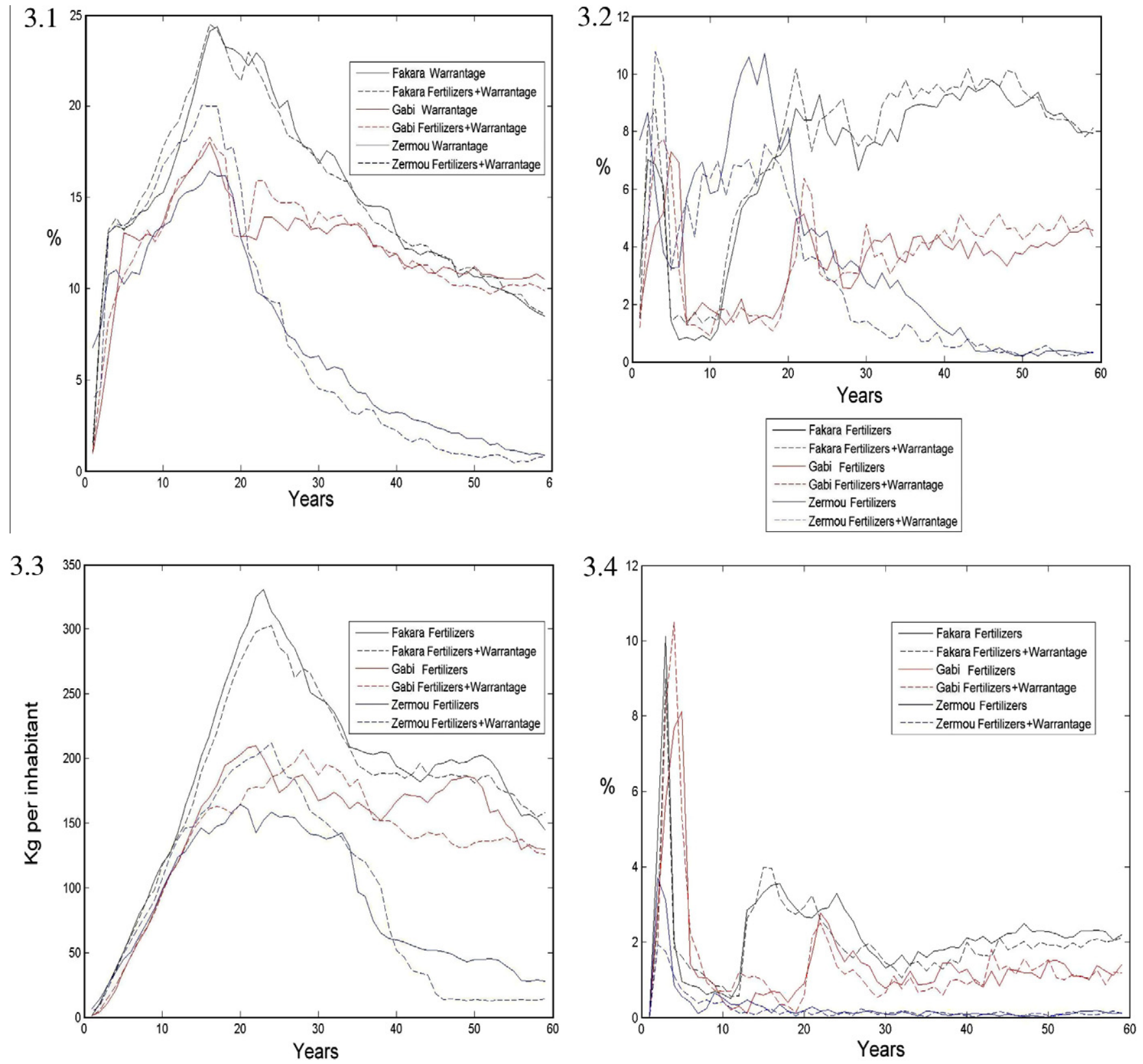

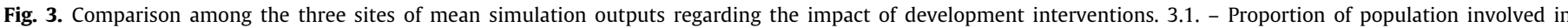

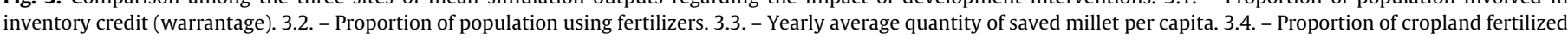
by inorganic fertilizers.

from activities other than farming are thus used for activities that promise a higher return, such as migration. From year 20 onwards, one can observe that the proportion of population using fertilizer and the proportion of fertilized land reach a higher value at the Fakara than at Gabi, which may be explained by an initially lower fertility level at the Fakara. For the case where arable land remains available, the Gabi population appears less interested in inorganic fertilizers. One may thus suppose that inorganic fertilizers are not attractive as long as fertile land is still easy to acquire. Present-day figures for a fully occupied Gabi site show that two thirds of the farmers actually use inorganic fertilizers. Therefore, simulating present-time inorganic fertilizer use would require simulating a situation with all available cropland being cultivated at Gabi.

Zermou farmers show a different behavior at the start of simulations, largely due to their particular strategy of field expansion for compensating their lower yields. The first 25 years show that, as long as the manpower/acreage ratio remains favorable and new fields can still be cleared, one observes a growing use of inorganic fertilizers. As off the moment, once all available cropland is occupied, which leads to a drastic reduction in the interest for farming, fertilizer use declines, essentially to zero.

\subsubsection{Two development interventions targeting different groups of populations}

The simulation outputs corresponding to a scenario combining fertilizer access and inventory credit shows that there is no synergy between inventory credit and inorganic fertilizers use strategy (Fig. 3), suggesting that the logics and even the population groups concerned by the two activities may be distinct. As fertilizer and inventory credit users at Zermou are too few, the analysis will fo- 
Table 2

Comparison between project user families and the average population for various indicators.

\begin{tabular}{|c|c|c|c|c|c|c|}
\hline \multirow{2}{*}{$\begin{array}{l}\text { For the sites of Gabi \& Fakara taken together } \\
\text { Family characteristics compared to the average population }\end{array}$} & \multicolumn{4}{|c|}{ Inorganic fertilizer using population } & \multicolumn{2}{|c|}{ Inventory credit using population } \\
\hline & (i) & $\Delta$ & (ii) & $\Delta$ & (i) & $\Delta$ \\
\hline Family head age & - & $\Uparrow$ & ++ & $\Uparrow$ & + & $\Uparrow$ \\
\hline Lineage & -- & $\Downarrow$ & 1 & $\Rightarrow$ & ++ & $\Rightarrow$ \\
\hline Family Size & - & $\Uparrow$ & + & $\Downarrow$ & ++ & $\Rightarrow$ \\
\hline Manpower & - & $\Rightarrow$ & 1 & $\Downarrow$ & ++ & $\Rightarrow$ \\
\hline Land size & - & $\Uparrow$ & ++ & $\Rightarrow$ & + & $\Uparrow$ \\
\hline Livestock & -- & $\Rightarrow$ & + & $\Rightarrow$ & ++ & $\Uparrow$ \\
\hline Income per capita & 1 & $\Rightarrow$ & + & $\Rightarrow$ & + & $\Uparrow$ \\
\hline Livestock per capita & - & $\Downarrow$ & - & $\Downarrow$ & ++ & $\Uparrow$ \\
\hline Land per capita & - & $\Rightarrow$ & - & $\Uparrow$ & + & $\Uparrow$ \\
\hline Manpower per capita & + & $\Uparrow$ & + & $\Downarrow$ & + & $\Rightarrow$ \\
\hline Manpower per cropped surface & 1 & $\Uparrow$ & - & $\Downarrow$ & ++ & $\Rightarrow$ \\
\hline Livestock per cropped surface & - & $\Rightarrow$ & - & $\Rightarrow$ & + & $\Uparrow$ \\
\hline
\end{tabular}

(i) - -: $-25 \%$ and less; -: -10 to $-25 \%$;: $10 \%$; +: $10-25 \%$; + : $25 \%$ and more; $\Downarrow:-25 \%$; $\Rightarrow: \pm 25 \%$; : $+25 \%$.

cuss on Gabi and Fakara only. Families using inorganic fertilizers all have in common a higher manpower per capita but a lower land acreage per capita and lower livestock per surface than the average population. They can be split into two groups (Table 2):

- "Small young disadvantaged but growing families": their average lineage value is low (1.6 vs. 2.8 for the whole population), suggesting that they may have been disadvantaged regarding land access due to social tenure discriminations. Families are small, manpower and owned land is low. The head of the family is younger than average ( 35 years-old vs. 43). However, the higher manpower/capita ratio allows the family to sustain itself by diversifying income sources (millet fields, migration, and after a few years, livestock sales and gardening). It also allows the use of inorganic fertilizers by succeeding in all the millet cropping cycle steps, particularly the higher manpower requirement for weeding. This group represents at most 30\% of the inorganic fertilizer users around the 15th year, and then declines, eventually disappearing around the 40th year of the simulation.

- "Large old but shrinking families": the family head is far older than average (61 years-old vs. 43). Because of the non-cooperative family organization (Saqalli et al., 2010), elder children leave once they get married, taking with them some parts of the livestock and manpower. The high level of income and livestock per capita allow mobilizing enough funds for compensating the declining manpower ratio. The group size at the beginning of the simulations is higher by $25 \%$ in the scenario combining both inventory credit and inorganic fertilizers compared to the scenario with only inorganic fertilizers.

One should understand that these groups remain stable but families are evolving along a sequence. For instance, one family may belong to the first group, leave the group and then enter the second group. Anyhow, inorganic fertilizers seem to be used only by families in transition: they cannot be used by the poorest as it is too expensive, and the wealthiest can use other assets, particularly manpower and livestock (especially small livestock) in a context where land is still not a constraint.

For the two sites, inventory credit users are members of a unique group that can be described as "large better-settled families": their average lineage value is quite high (3.2 vs. 2.8), and the family head is somewhat older than average ( 48 years-old vs. 43 ). Families are big and growing, with larger number of young adults than average and consequently, manpower and owned land are higher as well. Inventory credit seems to be an alternative to livestock as an income saving tool, but only families that are able to maintain a capacity for savings get involved.

\section{Discussion and conclusions}

The simulations indicate that the three sites evolve along different trajectories due to their differing biophysical potential, which influences demographic growth but even more so the manpower ratio and the involvement in farming activities. Social and environmental indicators suggest some degree of sustainability but also the fragility of such systems under the simulated conditions, e.e., as long as new land remains available for cropping. However, particularly regarding Gabi, the temporal scale may have to be extended in order to simulate the current conditions. Indeed, nearly all potential cropland is currently being cropped at this latter site. The fragility of the system may thus even be higher in reality at Gabi than suggested by the simulation outputs.

Our model indicates that the impact of both development interventions is also conditioned by the local biophysical conditions. Involvement in inventory credit and inorganic fertilizer projects occurs only at sites where millet savings are possible, which is not the case at Zermou. Even so, involvement at Gabi and the Fakara remains limited, with a greater impact of inventory credit than fertilizers. These interventions actually require an investment capacity that few people do have at the Fakara and Gabi. This capacity is largely conditioned by the food requirement of each family in relation to its manpower. Consequently, only a maximum of $25 \%$ of the population engages in the simulated development interventions. At the Fakara, inventory credit is met with some success only during periods when enough manpower was available. At the more fertile site of Gabi, the interventions, whose aim is to promote agricultural intensification, do not have a large success as long as new fertile land remains available. However, due to the limited temporal scale, simulations do not provide information regarding a possible intensification process in a future context of land scarcity. Therefore, these two interventions should be viewed as support tools for only a limited portion of the population capable of going beyond the survival level, but not as a generic povertyalleviation panacea.

More generally, one can state that development projects often focus solely on the costs/advantages of a development intervention, assuming that such interventions will generate their own demand. A detailed modeling of the target societies, as was done here, rather shows that the size of the target groups for such interventions is fairly limited and strongly dependent on the biophysical constraints of the project site.

Project operators had better propose a variety of interventions, assuming that an intervention, whatever its intrinsic quality, will not encounter the interest of the entire population. Unfortunately, many planning programs use a "fundraiser-oriented marketing approach", often suggesting that a given intervention can succeed 
across a whole country even though the data and information on which the marketing relies are based on one local experience. By suggesting the strong impact of local social and biophysical factors and their local variability and distribution, our simulations allow us to advocate a new marketing approach for development interventions, better focusing on the local and variable population demands and specificities.

The present model results from a step-by-step construction process, which may still be improved in the future. For instance,

- labor and land markets were not implemented. While land markets are still almost completely absent at the sites of Zermou and Fakara, they do exist at Gabi, particularly for fields suitable for irrigation, which is obvious in a context of total land occupation that we did not implement. There are still almost no labor markets in Zermou, but Tahirou and Sanders (2005) and our own observations in Fakara suggest that this activity, while almost absent in the 90's (Ada and Rockström, 1993; LoireauDelabre, 1998; Mounkaïla, 2003), is growing very rapidly at those two sites.

- Although the literature often reports the Fulani to represent around $10 \%$ of the local population, figures from Barbier and Hazell (2000) suggests that they may actually represent around one third of the total population in the Fakara. As they have a different land and livestock use mode, including their presence in a model may transform outputs and further prospectives.

- Yamba (2004) has noticed a generalization of divorce. Since no data are actually available at the national level, the phenomenon was not modeled but this factor may in practice have a strong impact since women appear to resort to divorce at least once in a lifetime, bringing with them assets, particularly small livestock. This may provide more independence to the womendriven local economy and more variability in the wealth accumulation processes at family level (Turner, 1999).

This model was built on the hypothesis that the present-time evolution of any farming system is best represented and understood by integrating the system history and inertia, thereby minimizing qualitative judgements. To start the village simulation from its foundation appears more relevant than rebuilding a general tenure or family pattern as "a copy" of an observed situation. Whereas one can find villages that are less than 60 years old at the Zermou or the Fakara sites, none can be found at Gabi. Therefore, because their dynamics are more ancient than the duration of the simulation period (60 years), the present dynamics of some Nigerien areas, such as Gabi, cannot be simulated properly. The simulated outputs may well represent what could have been observed at the time, but no longer correspond to the present time.

New phenomena may come up in simulations longer than the 60 years, as land scarcity will then appear at the different sites. However, pursuing the simulation beyond 60 years may lead to practical computing limitations as the computing time requirements rise exponentially. In any case, pursuing the simulations without including some adaptation processes of the population will obviously lead to population and environmental crashes in a Malthusian approach. New simulation approaches that include social evolutions may bridge the gap between sociological and agroeconomic analyses and thereby open up the prospects of different futures for these societies.

\section{Acknowledgements}

Authors are thankful and indebted to all interviewed villagers for their great patience. We acknowledge the contribution of Dr. Tahirou for his valuable advice on anthropological questions, Pr. F. Gaspart (UCL), P. Bommel and Dr. C. Le Page (CIRAD-TERA) for their helpful comments on the first versions of the manuscript. This research was carried out as part of the ICRISAT-led "Decision-support program" financed through the Belgian Directorate General for Development Cooperation (DGCD).

\section{References}

Ada, L., Rockström, J., 1993. Diagnostic sur le système agraire du Zarmaganda central (Niger). M.Sc. Agronomy. INA-PG, Paris.

Ahrweiler, P., Gilbert, N., 2005. Caffè Nero: the evaluation of Social Simulation. Journal of Artificial Societies and Social Simulation 8, 4.

Akponikpe, P.B.I., Minet, J., Gerard, B., Defourny, P., Bielders, C.L., 2011. Spatial fields dispersion as a farmer strategy to reduce agro-climatic risk at the household level in pearl millet-based systems in the Sahel: a modeling perspective. Agricultural and Forest Meteorology 151 (2), 215-227.

Alacs, P., 2004. Complexity and uncertainty in the forecasting of complex social systems. Journal of Interdisciplinary Description of Complex Systems 2 (1), 8894

Amblard, F., Phan, D., 2006. Modélisation et simulations multi-agents: application pour les sciences de l'Homme et de la Société. Hermès, Paris.

AQUADEV, 2006. Suivi de la sécurité alimentaire; Région de Zinder: Départements de Mirriah, Tanout et Gouré; Situation octobre 2006. Bulletin Trimestriel 6-13. AQUADEV, Zinder.

Ayantunde, A., Williams, T.O., Udo, H.M.J., Fernandez-Rivera, S., Hiernaux, P., Van Keulen, H., 2000. Herders' perceptions, practice, and problems of night grazing in the Sahel: case studies from Niger. Human Ecology 28 (1), 109-130.

Ayantunde, A., Fernandez-Rivera, S., Hiernaux, P., Van Keulen, H., Udo, H.M.J., 2002 Day and night grazing by cattle in the Sahel. Journal of Range Management 55 (2), 139-143.

Badamassi, F., 2006. Le warrantage au Niger: Une technique de crédit pour lutter contre la pauvreté rurale? Cas des femmes de l'Union Tonougakay Ni Bonga de Saboudey Carre. M.B. Finance, Ecole Supérieure de Commerce de Dakar, Dakar.

Bah, A., Touré, I., Le Page, C., Ickowicz, A., Diop, A.T., 2006. An agent-based model to understand the multiple uses of land and resources around drillings in Sahel. Mathematical and Computer Modeling 44, 513-534.

Barbier, B., Hazell, P.B.R., 2000. Declining access to transhumant areas and sustainability of agropastoral systems in the semi-arid areas of Niger. In: Hazell, P.B.R. (Ed.), Property Right and Collective Action. IFPRI, Washington, pp. 371-395.

Biershenk, T., Chauveau, J.-P., Olivier de Sardan, J.-P., 2000. Courtiers en développement. Les villages africains en quête de projet. APAD-Karthala, Paris.

Bogdan, R., Taylor, S.J., 1975. Introduction to Qualitative Research Methods. A Phenomenological Approach to the Social Sciences. John Wiley \& Sons, New York.

Bousquet, F., Le Page, C., 2004. Multi-agent simulations and ecosystem management: a review. Ecological Modeling 176 (3-4), 313-332.

Bousquet, F., Lifran, R., Tidball, M., Thoyer, S., Antona, M., 2001. Agent-based modelling, game theory and natural resource management issues. Journal of Artificial Societies and Social Simulation 4, 2.

Chambers, R., 1994. Participatory rural appraisal (PRA): analysis of experience. World Development 22 (9), 1253-1268.

d'Herbès, J.-M., Ambouta, K., Peltier, R., 1997. Fonctionnement et gestion des écosystèmes forestiers contractés sahéliens. John Libbey, Paris.

de Janvry, A., Sadoulet, E., 2003. Progress in the modeling of rural households behavior under market failures. In: de Janvry, A., Kanbur, R. (Eds.), Poverty Inequality and Development, Essays in Honor of Erik Thorbecke. Kluwer Publishing, Los Angeles.

de Rouw, A., 2004. Improving yields and reducing risks in pearl millet farming in the African Sahel. Agricultural Systems 81 (1), 73-93.

de Rouw, A., Rajot, J.-L., 2004. Nutrient availability and pearl millet production in Sahelian farming systems based on manuring or fallowing. Agriculture, Ecosystems and Environment 104 (2), 249-262.

Decoudras, P. -M., 1990. L'aide internationale au Niger. Politique Africaine 38, 8796.

Deffuant, G., Amblard, F., Duboz, R., Ramat, E., 2002. Une démarche expérimentale pour la simulation individu-centrée. In: Proceedings of the 10th Rochebrune Days Interdisciplinary Meetings on Complex Natural \& Artificial Systems. ENST LISC, Megève.

Demont, M., Jouve, P., Stessens, J., Tollens, E., 2007. Boserup versus Malthus revisited: evolution of farming systems in northern Côte d'Ivoire. Agricultural Systems 93 (1-3), 215-228.

Dollar, D., Levin, V., 2006. The increasing selectivity of foreign aid, 1984-2003. World Development 34 (12), 2034-2046.

Dorfman, R., 1979. A formula for the Gini coefficient. The Review of Economics and Statistics 61 (1), 146-149.

Gastellu, J.-M., Dubois, J-L., 1997. En économie: l'unité retrouvée, la théorie revisitée. In: Ménages familles en Afrique: Approches des dynamiques contemporaines. Les Etudes du CEPED, vol. 15, pp. 75-97.

Gavian, S., Fafchamps, M., 1996. Land tenure and allocative efficiency in Niger American Journal of Agricultural Economics 78 (2), 460-471.

Gérard, B., 2002. Projet Aide à la décision: full proposal for the DGCD, Bruxelles

Gérard, B., 2005. ICRISAT Agronomic Results from the Global Linear Modelization of Demonstration Tests Fields' Data. ICRISAT Report, Niamey. 
Gérard, B., Fatondji, D., Dandois, C., Manyame, C., Bielders, C., 2007. Toward farm specific recommendations for the use of mineral fertilizers in Sahelian croplivestock systems. In: Proceedings of the 16th International Symposium of the International Scientific Centre of Fertilizers (CIEC), Ghent

Graef, F., Haigis, J., 2001. Spatial and temporal rainfall variability in the Sahel and its effects on farmers' management strategies. Journal of Arid Environments 48 (2) $221-231$.

Hambally, Y., 1999. Mode d'intervention et pratiques paysannes au Niger. Ph.D. Geography. EDHESS, Paris.

Harragin, S., 2006. The Cost of Being Poor: Markets, Mistrust and Malnutrition in Southern Niger 2005-2006, Save the Children, London.

Jouve, P., 2003. Typologie des agrosystèmes villageois du département de Maradi (Niger) propositions pour un programme de recherche-développement. Collection Doc. Systèmes Agraires 3, Montpellier.

Koning, N., Smaling, E., 2005. Environmental crisis or 'lie of the land'? The debate on soil degradation in Africa. Land Use Policy 22 (1), 3-11.

La Rovere, R., 2001. Livestock Roles and Agro-environmental Sustainability of Sahelian Niger Mixed Crop-livestock Systems Under Intensification. Ph.D. Geography. International Livestock Research Institute, University of Hohenheim, Hohenheim.

Lambin, E.F., Turner, B.L., Geist, H.J., Agbola, S.B., Angelsen, A., Bruce, J.W., Coomes, O.T., Dirzo, R., Fischer, G., Folke, C., Goerge, P.S., Homewood, K., Imbernon, J., Leemans, R., Xiubin, L., Moran, E.F., Mortimore, M.J., Ramakrishnan, P.S., Richards, J.F., Skanes, H., Steffen, W., Stone, G.D., Svedin, U., Veldkamp, T.A. Vogel, C., Jianchu, X., 2001. The causes of land-use and land-cover change: moving beyond the myths. Global Environmental Change 11, 261-269.

Lavigne-Delville, P., 1998. Harmonising formal law and customary land rights in French-speaking West Africa. In: Proceedings of Politique des structures et action foncière au service du développement agricole et rural. CNASEA, 32, La Réunion.

Lavigne-Delville, P., 1999. Impasses cognitives et expertise en sciences sociales: réflexions à propos du développement rural en Afrique. GRET Coopérer aujourd'hui. 9.

Le Bris, E., Le Roy, E., Mathieu, P., 1991. L'appropriation de la terre en Afrique Noire, Manuel d'analyse, de décision et de gestion foncières, Karthala, Paris.

Loireau-Delabre, M., 1998. Espaces Ressources Usages: Spatialisation des Interactions Dynamiques entre les systèmes sociaux et écologiques au Sahel Nigerien, site de Banizoumbou, Niger. Ph.D. Geography. Université Montpellier 3, Montpellier.

Luxereau, A., Roussel, B., 1997. Changements écologiques et sociaux au Niger. L'Harmattan, Paris.

Marinho, E.C.deA., 2007. Humanitarian Aid and Famines, A Bidirectional Relationship. Working paper.

McCarthy, N., Swallow, B., Kirk, M., Hazell, P.B.R., 2000. Property Rights, Risk, and Livestock Development in Africa. IFPRI. Nairobi.

Médecins Sans Frontières, 2005. Urgence Niger: Payer ou Mourir. Chiffres remis à jour le 28 juillet 2005. 19

Mortimore, M.J., Adams, W.M., 2001. Farmer adaptation, change and 'crisis' in the Sahel. Global Environmental Change 11 (1), 49-57.

Mortimore, M.J., Tiffen, M., Yamba, B., Nelson, J., 2001. Synthèse sur les évolutions à long terme dans le département de Maradi, Niger 1960-2000. Drylands Research. Crewkerne.

Mounkaïla, H., 2003. De la migration circulaire à l'abandon du territoire local dans le Zarmaganda (Niger). Revue Européenne des Migrations Internationales 18 (2), 161-187.

Muehlig-Versen, B., Buerkert, A., Bationo, A., Roemheld, V., 2003. Phosphorus placement on acid arenosols of the West African Sahel. Explanatory in Agriculture 39, 307-325.
Ouédraogo, S., 2005. Intensification de l'agriculture dans le plateau central du Burkina Faso: Une analyse des possibilités à partir des nouvelles technologies. Ph.D. Economy. Rijksuniversiteit Groningen, Groningen.

Pender, J., Tahirou, A., Ndjeungua, J., Gérard, B., Kato, E., 2006. Impacts of inventory credit, input supply shops and fertilizer micro-dosing in the dryland of Niger. In: Proceedings of the 26th Conference of the International Association of Agricultural Economists, Brisbane.

Rain, D., 1999. Eaters of the dry season: circular labor migration in the West African Sahel. West View Press, Oxford.

Reardon, T., 1994. La diversification des revenus au Sahel et ses liens éventuels avec la gestion des ressources naturelles par les agriculteurs. In: Benoît-Cattin, M. (Ed.), Promotion de systèmes agricoles durables dans les pays d'Afrique soudano sahélienne. FAO CTA CIRAD, pp. 65-77.

Saqalli, M., Bielders, C.L., Defourny, P., Gérard, B., 2010. Simulating rural environmentally and socio-economically constrained multi-activity and multi-decision societies in a low-data context: a challenge through empirical agent-based modelling. Journal of Artificial Societies and Social Simulation 13, 2.

Saqalli, M., Caron, P., Defourny, P., Issaka, A., 2009. The PBRM (perception-based regional mapping): a spatial method to support regional development initiatives. Applied Geography 29, 358-370.

Saqalli, M., 2008. Populations, Farming Systems and Social Transitions in Sahelian Niger: An Agent-based Modelling Approach. Ph.D. in Agronomy. Université catholique de Louvain, Louvain-la-Neuve <http://www.padniger.net>.

Tabo, R., Bationo, A., Gérard, B., Ndjeungua, J., Marchal, D., Amadou, B., Annou, G., Sogodogo, D., Sibiry, J.B., Hassane, O., Diallo, M., Koala, S., 2007. Improving cereal productivity and farmers' income using a strategic application of fertilizers in West Africa. In: Bationo, A. (Ed.), Advances in Integrated Soil Fertility Management in Sub-Saharan Africa: Challenges and Opportunities. Springer, Netherlands, pp. 201-208.

Tahirou, A., Sanders, J.H., 2005. Stages and determinants of fertilizer use in semiarid African agriculture: the Niger experience. Agricultural Economics 32 (2), 167179.

Timera, M., 2001. Les migrations des jeunes sahéliens: Affirmation de soi et émancipation. In: Collignon, R., Diouf, M. (Eds.), Les jeunes: hantise de l'espace public dans les sociétés du Sud? Karthala, Paris 37-49.

Turner, M.E., 1999. Merging local and regional analyses of land use change: the case of livestock in the Sahel. Annals of the Association of American geographers 89 (2), 191-219.

Verhagen, H., Smit, R., 2003. Multi-agent System as Simulation Tools for Social Theory Testing. Erasmus Working Paper. Erasmus University, Rotterdam.

Watkins, K., von Braun, J., 2004. Time to Stop Dumping on the World's Poor. OXFAM-IFPRI.

Waziri Mato, M., 2000. Les cultures de contre-saison dans le sud de la région de Zinder (Niger), Ph.D. Geography. Université de Lausanne, Lausanne.

Wesel, A., Rajot, J. -L., Herbrig, C., 2000. Influence of shrubs on soil characteristics and their function in Sahelian agro-ecosystems in semi-arid Niger. Journal of Arid Environments 44 (4), 383-398.

Yamba, B., 2004. Les mutations des systèmes agraires et des modes d'usage des ressources naturelles dans la zone centrale du Niger. Revue de géographie alpine 92 (1), 97-110

Yamba, B., 2005. Observatoire de Maradi-Mayahi-Dakoro, Rapport de caractérisation, Min. de l'Hydraulique, de l'Environnement et de la Lutte contre la Désertification, Rép. Du Niger, Niamey, Niger. 